nance of public libraries and public school libraries. The public library as a part of the educational system. Instruction in the use of books and libraries. Constructive work illustrating the making of a book. Courses given in colleges, normal schools, and public libraries.

2. Children's Books and Libraries. - Children's books and periodicals. Illustrations of children's books. Children's reading-rooms; their aim, character of books and periodicals, the attendants, reading lists, and furnishings. Maxon book-mark. Library league. Bulletins for libraries and schoolrooms. Home libraries.

3. Organization and Administration.-Ordering and buying. Accessioning. Shelf-listing. Charging systems. Classification; based on the Dewey Decimal Classification. Modifications of the system in this library explained. Cataloguing; the cataloguing will be taught according to the New York State Library School Rules adapted to a school library.

4. Bibliography and Reference Work. Comparative value of dictionaries, indexes, cyclopædias, and handbooks. Trade bibliography and bibliography of special subjects. Book reviews and magazines.

5. Pictures, Posters, Maps, and Charts. Collecting, mounting, arrangement, and use. Exhibits. Care and preservation. Note-taking and library devices.

6. Work of Library Schools and Associations. - American library associations. Library section of the National Educational Association. State library associations. Library sec- tions of state teachers' associations. City library clubs. Traveling libraries; work done in New York and Wisconsin. State library commissions. Farmers' reading courses. Instruction in library economy; University of Illinois, New York State Library, Pratt Institute, Drexel Institute, summer courses at University of Wisconsin and Amherst College, apprenticeship in public libraries.

7. History of the Making of Books. - Manuscripts. Illuminating. Illustrating. Printing. Binding.

\section{REFERENCES:}

New York State Library School Rules for Catalogue, Accession-hook, and Shelf-list. Library Bureau, 1899. Catalogue of A.L. A. Library, 5,000 volumes for a popular library selected by the American Library Association and shown at the World's Fair. U. S. Bureau of Education, 1893. A. L. A. list of subject headings for a dictionary catalogue. Library Bureau. Library Bureau Catalogue, containing lists of library tools and fittings. Plummer. Hints to Small Libraries. Tuslova and Comba, New York, 1898. Public Library Handbook by the Denver Public Library. Carson, Harper, I 894. Leypoldt and Iles. List of Books for Girls and Women and Their Clubs. Library Bureau, 1895. Dana. Library Primer. Library Bureau, 1899. Sargent. Reading for the Young, and Supplement. Houghton, 1896. Hewins. List of Books for Girls and Boys. Library Bureau. Files of the Library Journal and Public Libraries. Various publishers' catalogues and bulletins of libraries.

\title{
Department of Music
}

\section{Helen Goodrich}

The purpose of this course is to lead teachers to understand and produce valid musical effects without great technical proficiency. It will endeavor to make clear the relation between thought and emotion and the musical means of expression. There is a vast amount of dormant capacity among so-called unmusical people. We may look forward to beautiful and joyous self-expression in singing for practically all children as soon as the standard as to technical

\section{Bertha Payne}

requirements and material is corrected by reference to their real needs, mental, moral, and physical.

The plan of this course includes much class-drill in the fundamentals of natural tone-production, and in song-singing in parts and in unison. Exercises in speech will be given as a means of securing purity of vowel sounds, and smooth, exact consonant formation, together with exercises for control of the breath in singing. Con- 
nection between text and music will be worked out, looking toward a fuller expression of thought and emotion. Melodies will be studied as material for work in pitch, rhythm and sight-reading. There will be suggestive talks upon the relation of singing to speech, science-work, history, and literature, geography, and physical culture; also, upon folk-songs.

The subject of choice of songs will be discussed throughout the course. The classical type, the sentimental, and the Froebelian will be discussed, and the marks of a good or bad song will be shown, with illustrations.

I. Breathing: Exercises for developing diaphragm control and strength. Exhalation on vowel sounds.

II. Speech: Exercises for evolving a singing tone from speech. Drill upon pure vowel coloring and consonants.

III. Tone Production: Poise, attack, physiological succession of the vowels in their relation to voice development. Balance between registers.
IV. Studies: Sight-reading and intervaldrill by means of melodic studies developed from known songs. Scale work-major, minor, chromatic.

V. Song Study: Rhythm; attack; meaning and relation of text and tune.

VI. Historical Development: Expression of religious feeling; relation to national life, to rhythmic movement. Effect of environment upon musical expression; songs of the mountains, sailor songs, wanderer's songs, trade songs, lullabies, marching songs. Correlation of music, elocution, science, literature, and history. LIST OF SONGS RECOMMENDED FOR STUDY.

Children's Songs, by Reinecke, Rheinberger, Schumann, Brahms, Elliott, Gilchrist, Eleanor Smith.

Folk-Songs: Collection of Irish Songs, Villiers Stanford; Pan Pipes (Old English); Ausländische Liederschatz (Peters' Edition); Internationales Volksliederbuch, Reimann; Songs of Life and Nature, Eleanor Smith; Historical Specimens, Vol. K, Curwen; National Music, Carl Engel.

Note.-The songs published in the July Course of Study will be used in these classes. It is suggested that those who intend taking this course should familiarize themselves with the text of the songs.

\section{Round Table Meetings}

\section{Held by the Heads of Departments}

As announced on the program, every afternoon, from $3: 30$ to $4: 10$, will be devoted to round table meetings in which the heads of departments will discuss questions relating to their particular subjects. Col. Parker's outlines, considering arithmetic as a study in measuring quantity, and Mrs. Washburne's, relating the work of the home and the school, belong to this course and are given below:

\section{A Study in Measuring Quantity Francis W. Parker}

I. The function of Arithmetic is to measure quantity.

(a) Space and magnitude are measured

I. By length or distance. Feet, yards, miles, etc.
2. By areas, length and breadth, square inches, square yards, acres, etc.

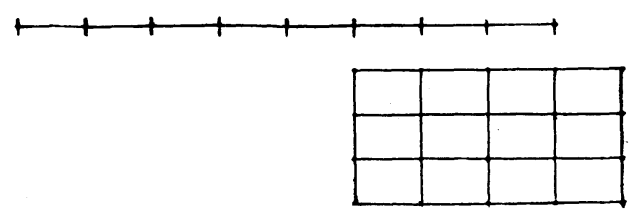

3. By volume, length, breadth, and thickness. (b) Bulk. is measured by pecks, bushels, etc. (c) Gravitation or weight is measured by pounds, tons, etc. (Scales.) (d) Force is measured by horse power, pounds of steam, volts and amperes of electricity, etc. (e) Time is measured by minutes, hours, centuries, etc. (Face of clock.) (f) Equivalents in value are measured by cents, dollars, francs, marks, pounds, etc. (g) Single things like trees, houses, men, beasts, may be measured by ones or any unit of ones. 